\title{
A Rabbit Model of Avascular Necrosis of Femoral Head Using Surgical Trauma and Systemic Steroids
}

\author{
Cerrahi Travma ve Sistemik Steroid Uygulaması ile Tavşanlarda Femur Başı \\ Avasküler Nekroz Modeli
}

(i) Hakan ÖZBEN

Koç University Faculty of Medicine, Department of Orthopedics and Traumatology Hand Surgery and Microsurgery, İstanbul, Turkey

\begin{abstract}
Objective: Avascular necrosis of the femoral head (ANFH) is a disease caused by the diminished circulation of the femoral head. The incidence of the disease is increasing and it has heavy socioeconomical burden. Animal models are indispensable for the development of new treatments for bone avascular necrosis. There is not any reliable animal model for simulating the early stages of femoral head osteonecrosis. The aim of this study is to present an animal model of femoral head osteonecrosis induced by systemic steroid use combined with surgery.

Methods: Six New Zealand White rabbits were divided into 3 groups. Each group contained 4 femoral heads. For the induction of osteonecrosis, every hip underwent surgical dislocation followed by cauterization of extraperiosteal vessels around the femoral head and ligamentum teres resection. A single dose intramuscular steroid was administered to each rabbit. Rabbits were sacrificed at $2^{\text {nd }}, 4^{\text {th }}$ and $6^{\text {th }}$ weeks and femoral heads were sent to histological evaluation.

Results: The femoral heads showed typical signs of avascular necrosis at the end of $2^{\text {nd }}$ week. In addition to osteocyte loss and marrow necrosis, there was also new osteoblast formation at the end of $4^{\text {th }}$ week. At the end of $6^{\text {th }}$ week, epiphyseal new bone formation next to large necrotic areas were visible.

Conclusion: These results suggest that the single steroid administration combined with hip luxation and cauterization of neck vessels may create femoral head osteonecrosis in rabbits in a repeatable and reliable manner. This model can be presented as an alternative model for the new studies on the treatment of femoral head avascular necrosis in the early stage.
\end{abstract}

Keywords: Avascular necrosis, femoral head, rabbit

\section{ÖZ}

Amaç: Femur başı avasküler nekrozu (FBAN), femur başının kanlanmasındaki azalmadan kaynaklanan, görülme sıklığı giderek artan ve ağır sosyo-ekonomik etkileri olan bir hastalıktır. Hayvan modelleri, kemiklerdeki avasküler nekrozlar için yeni tedavi yöntemlerinin oluşturulmasında vazgeçilmezdir. Halen, erken dönem FBAN'yi simüle edebilen güvenilir bir hayvan modeli yoktur. Bu çalışmanın amacı, cerrahi ve sistemik steroid kombinasyonu ile tavşanda FBAN modeli oluşturmaktır.

Yöntemler: Altı Yeni Zelanda beyaz tavşanı 3 gruba ayrıldı. Her grup 4 femur başı içermekteydi. FBAN oluşturmak için her kalçaya cerrahi olarak dislokasyon, femur boynu periosteal damarların koterizasyonu ve ligamentum teres eksizyonu yapıldı. Sonrasında her tavşana tek doz intramusküler steroid uyguland. Gruplardaki hayvanlar sırasıyla 2., 4. ve 6. haftalarda sakrifiye edildi ve tüm femur başları rezeke edildi. Femur başları histolojik olarak avasküler nekroz bulguları açısından değerlendirildi.

Bulgular: İkinci haftanın sonunda incelenen femur başlarında tipik histolojik avasküler nekroz bulguları mevcut idi. Dördüncü hafta sonunda alınan örneklerin yapılan histolojik değerlendirmelerinde osteosit kaybı ve kemik iliği nekrozuna ek olarak osteoblast oluşumları görüldü. Altıncı hafta sonunda yapılan incelemelerde epifizyel alanlarda geniş kemik iliği nekrozlarına ek olarak yeni kemik oluşumları görüldü.

Sonuç: Bu sonuçlar, femur başı luksasyonu ve koterizasyonu ile tek doz steroid uygulamasının tavşanlarda güvenilir ve tekrarlanabilir şekilde femur başı nekrozu oluşturduğunu göstermektedir. Bu model, femur başı osteonekrozlarının erken dönem tedavisi araştırmalarında kullanılabilecek bir seçenek olarak sunulabilir.

Anahtar Sözcükler: Avasküler nekroz, femur başı, tavşan
Address for Correspondence: Hakan ÖZBEN, Koç University Faculty of Medicine, Department of Orthopedics and Traumatology Hand Surgery and Microsurgery, İstanbul, Turkey

E-mail: hakanozben81@gmail.com ORCID ID: orcid.org/0000-0003-1844-3064
Received: 26.02 .2019

Accepted: 28.08.2019

Cite this article as: Özben H. A Rabbit Model of Avascular Necrosis of Femoral Head Using Surgical Trauma and Systemic Steroids. Bezmialem Science 2020;8(2):133-7. 


\section{Introduction}

Avascular necrosis of the femoral head (ANFH) is a progressive and functionally restrictive disease. Its etiologic factors include systemic steroid use, alcoholism, blood diseases, radiotherapy, trauma and disbaric diseases (1). Bleeding of the femoral head decreases due to either direct trauma (fractures of the femoral neck) or increased intraosseous pressure (2). ANFH most commonly affects the population aged between 20 and 50 years (3). If left untreated, femoral heads may deform and collapse leading to permanent functional constraints. In this sense, ANFH can lead to severe social and economic problems.

Histologically, the first signs of ischemia in the bone can be seen in the bone marrow from the second day at the earliest. Marrow cell nuclei begin to not hold the stain histologically, and large round cavities filled with adipose tissue form (4). After the $15^{\text {th }}$ day, osteocyte lacunae are empty and cells on trabecular surfaces disappear (Figure 1). The new capillaries, fibroblasts, histiocytes and osteoclasts that break down the necrotic marrow and trabeculae appear at the border of the necrotic areas. In the ongoing process, new spongy bone is formed on the dead trabeculae (5).

Animal models are needed to assess the efficacy of new treatments developed for ANFH. None of these animal models are fully reliable. Since the etiopathogenesis of ANFH is not well known, it is also quite difficult to determine the criteria of a valid animal model. The most commonly used method in animal models is systemic steroid administration (6-8). Ethanol injection to femur head, heating of the femur head with microwave, freezing of the femur head with liquid nitrogen and then burning the femur neck with cerclage are the other methods present $(2,9,10,11)$.

The aim of this study is to present a technique in which surgical trauma and systemic steroid administration are combined as the ANFH model in rabbits. The hypothesis of the study is that with this model, the histological changes of ANFH in its early stages can be simulated.

\section{Method}

Six female New Zealand rabbits weighing 3 kilograms (Harlan Laboratories Srl, San Pietro al Natisone, Italy) were operated in the Inter-Departmental Animal Laboratory of Modena and Reggio Emilia University (Modena, Italy). The study was carried out following the approval of the Institutional Animal Experiments Ethics Committee of Modena and Reggio Emilia University (2012/07/16-57). ANFH induction was performed on every 2 hips of each animal. The rabbits were then divided into 3 groups; each group contained 4 femoral heads. The animals in the groups were sacrified in the $\mathrm{CO}_{2}$ chamber at the end of the $2^{\text {nd }}$ week, $4^{\text {th }}$ week and $6^{\text {th }}$ week respectively, and histological examination of the femoral heads was performed.

AVFH Induction Model: Each rabbit was given general anesthesia with $3 \%$ Sevorane following sedation with $1 \mathrm{mg} / \mathrm{kg}$ midazolam. Following proper surgery site cleaning and skin disinfection, the incision was made which centralised the trochanter major.
The Tensor Fascia Lata was cut longitudinally. Gluteus Medius muscle was removed from trochanteric adhesion site. The hip joint capsule was opened and the femoral head was luxated with lateral traction. The Ligamentum Teres was resected totally. The femoral neck was cauterized with bipolar cautery from the trochanteric area to the epiphyseal area (Figure 2). Cartilage in the femoral head was preserved. Then the hip was reduced. The joint capsule and subcutaneous tissue was closed with absorbant sutures, while skin was closed with non-absorbant sutures. The same procedure was applied to the other hip. A single dose of methylprednisolone was administered intramuscularly at a dose of $20 \mathrm{mg} / \mathrm{kg}$. Then the anesthesia was terminated. Each animal was given $2.5 \mathrm{mg} / \mathrm{kg}$ of enrofloxacin intramuscularly every day for 5 days as antibiotic prophylaxis.

Histological Examination: Animals in groups were sacrified in the $\mathrm{CO}_{2}$ chamber at the end of $2^{\text {nd }}$, $4^{\text {th }}$ and $6^{\text {th }}$ weeks. Femoral heads were osteotomized from their intertrochanteric regions. Femoral heads were stored in 10\% formalin solution for 2 days and decalcified for 21 days in rapid decalcification solution (BDH Laboratories, Pool, UK) containing 5\% acid formalin and

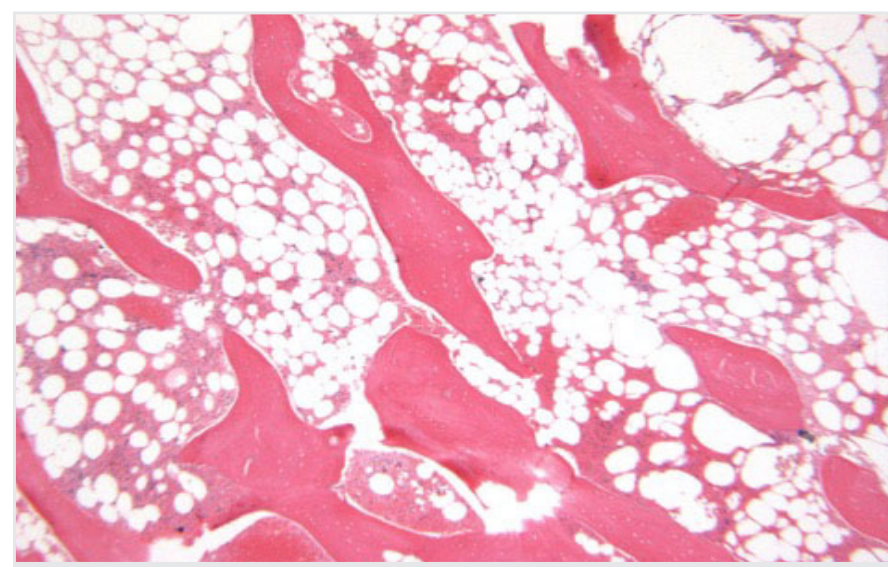

Figure 1. Classic histological findings in avascular osteonecrosis are coagulative necrosis of marrow cells and empty osteecyte lacunae in trabeculae (haematoxyleneeosin, 10X)

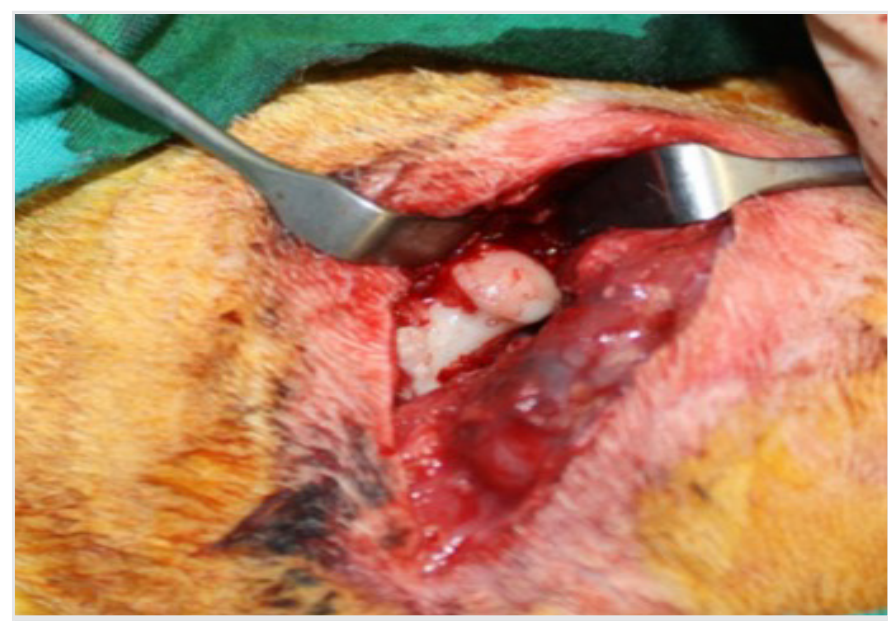

Figure 2. After the hip is dislocated, the femoral neck is cauterized with bipolar cautery, circumferentially 
$5 \%$ trisodium citrate. The femoral heads were then inserted into the paraffin. Three $\mu \mathrm{m}$-thick sections were deparaffinized and stained with Haematoxylene-eosin. All samples were examined under 10 and 40 magnification with Zeiss axioscope (Carl Zeiss, Germany). Signs of osteonecrosis such as the presence of empty lacunae, osteocytes with picnotic nuclei in bone trabeculae, bone marrow necrosis, bone marrow fat degeneration, thrombosis, and cartilage damage were noted. New trabecular bone formation, which indicated repair process, surrounding necrotic areas was also evaluated.

\section{Statistical Analysis}

In this experimental study, the images under the microscope were compared and the differences were stated as interpretations. Therefore, no statistical analysis was performed. Therefore, a headline such as "statistical analysis " will not be appropriate. Another experimental study published in your journal; "The effects Of Lucilia sericata Larval Secretions on The Expression of MicroRNAs that are Suggested to be Related with Wound Healing in Experimental Diabetic Rat Wound Model” also does not contain a headline such as statistical analysis.

\section{Results}

At the end of the second week, all 4 femur heads examined showed histologically typical signs of osteonecrosis, fatty degeneration of bone marrow and empty bone lacunae. The boundaries of the dead bone trabeculae were evident. Mesenchymal tissue and bone debris materials were visible at marrow distances. Of bone lacunae, $22 \%$ were empty. New bone formation was not observed (Figure 3).

The findings of osteonecrosis were more pronounced in the femoral heads collected at the end of the fourth week. The rate of empty bone lacunae without osteocytes reached $80 \%$ in some areas. Bone marrow necrosis and adipocyte hypertrophy and increase in the number of macrophages were noted. In addition, osteoblasts that began to appear around the necrotic bone sites were indicative of new bone formation (Figure 4).

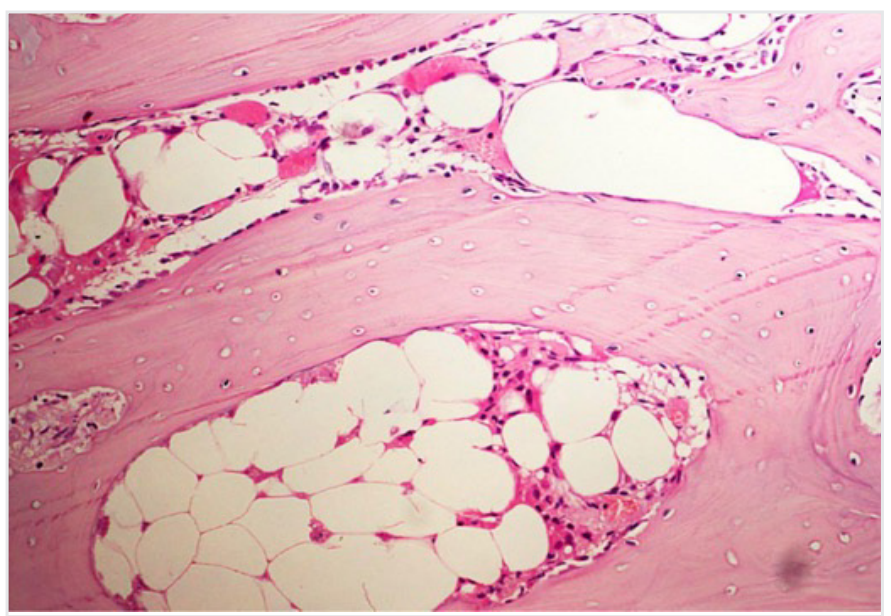

Figure 3. At the end of the second week, the number of cells in the femur heads decreases and necrotic debris and empty osteocyte lacunae are observed
Areas covered with widespread necrosis and irregular granulation tissue, as well as spontaneous bone regenerations were also evident in the femur heads examined at the end of the sixth week. The necrotic bone was covered with living bone tissue. Dead osteocytes and irregular fibrous tissue were still seen at the Centers of the old necrosis sites. The necrotic marrow areas in the pineal areas showed the extent of the damage (Figure 5).

All of the animals lived for the duration of the prescribed experiment. There were no complications, such as wound detachment or infection. Wound detachment caused by an animal biting the suture area was sutured again.

\section{Discussion}

Femoral head osteonecrosis is a common disease, affecting the relatively young population (2). Although its pathomechanism has not been definitively elucidated, it is assumed that there is an ischemic factor and blood loss problem in both traumatic and non-traumatic femoral head osteonecrosis (2). Pathologies caused by different etiologies are similar. Appropriate experimental animal models are needed to establish treatment and prevention facilities for ANFH.

In our study, surgical femoral head luxation, cauterization of extraperiosteal vessels of femoral neck and systemic steroids were used to create ANFH model in rabbits. Our histological results showed that this method was able to replicate early avascular necrosis in the head of the rabbit femur. In addition, we believe that this method we apply is more reliable and effective than other previously published models and creates a mechanism closer to pathomechanism of ANFH in human beings.

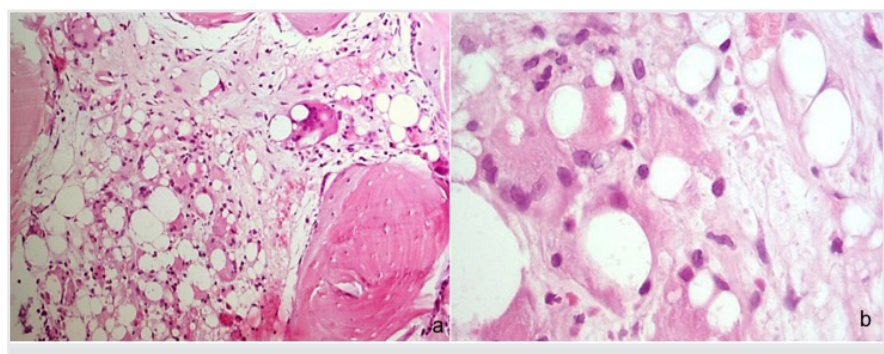

Figure 4. At the end of the fourth week, the bone marrow contains adipocytes and fibrotic tissue (a). Osteoblasts seen around their necrotic sites are a sign that the process of autoregeneration has begun (b)

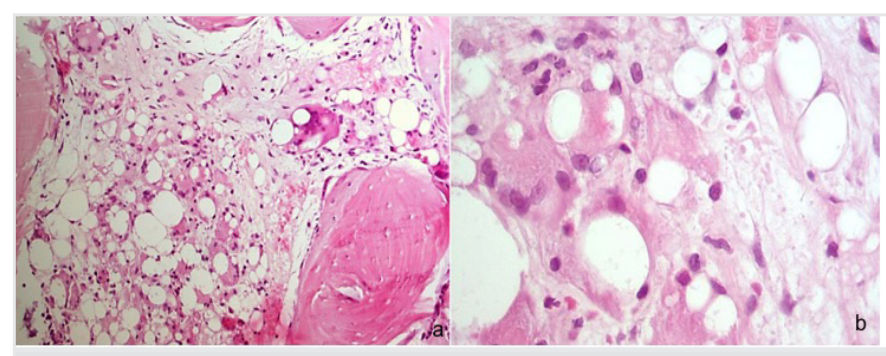

Figure 5. At the end of the sixth week the medullary canal is covered with irregular granulation tissue and necrosis (a). Osteoblasts initiate the formation of new bone tissue around necrotic trabeculae (b) 
Systemic steroid administration has been shown in previous publications to create osteonecrosis in rabbits $(7,10,12,13)$. However, almost all of these studies showed that osteonecrosis developed histologically in almost every part of the long bones, but osteonecrosis remained at a relatively low rate of $29 \%$, especially in the proximal epiphysis of the femoral head (10). Osteonecrosis state in metaphyses may not lead to joint destructions, such as subcondral osteonecrosses. Therefore, the animal model to be developed should create osteonecrosis, especially in the proximal femoral epiphysis. In our model, avascular necrosis developed in all of 12 femurs taken from every 6 rabbits. In addition, mortality rates ranging from $2 \%$ to $44 \%$ were reported in rabbits after high dose steroid administration $(7,13)$. The 6 rabbits used in our study did not have complications such as mortality, local or systemic infection which indicated that our model was reliable.

Different methods have been tried to create osteonecrosis only in the subchondral area of the head of the femur. Li et al. created heat damage with a microwave antenna sent from the subcapital area to the center of the femoral head after surgically exposing the femoral heads, and histologically verified the development of osteonecrosis (11). Zhang-hua et al. and Song applied liquid nitrogen to the cartilage in the load-bearing region of the femoral head after surgically exposing the femoral head to create ANFH in rabbits $(14,15)$. Manggold et al. injected pure ethanol into the thin tunnel they opened in the femoral head in their study on sheep (9). Although the findings of osteonecrosis could be seen histologically in these studies, bone damage was caused by thermal and chemical factors. In addition, cartilage damage developing in the middle and late stages of patients with ANFH was one of the first findings seen in studies using these thermal methods. Our study aimed to create disturbance in vascularization of the femoral head epiphysis, which was the main factor in etiology of avascular osteonecrosis, and as a result to create ANFH.

Another method to disturb vascularization of the femoral head has also been suggested by Hwang et al. (2). In that study, after the proximal femur was exposed to create traumatic ANFH, a tight cerclage wire was wrapped around the femur necks of one group of rabbits, while a cerclage wire was wrapped around the femur necks of another group and electric current was given to this wire by monopolar cautery. As a result, osteonecrosis was detected more in both 2 groups compared with the group who underwent systemic steroid administration alone (2). In our study, extraperiosteal circulation was blocked by burning the femoral neck vessels in a similar way. In addition, the endosteal circulation was disrupted by systemic steroid administration. In this way, it was predicted that the autoregeneration that would begin after ANFH was formed in the rabbit could be delayed.

As with all trials in rabbits, the weakness of our study was that 4 weeks after ANFH formation, autoregeneration-induced recovery began in rabbits. This situation causes completion of recovery of the femoral head before cartilage damage begins and makes it difficult to perform studies about experimental treatments aimed to prevent the arthrotic changes that will be seen in the late period.

\section{Conclusion}

ANFH models in animals are invaluable in the research of pathomechanism, prophylactic measures and treatment of the disease. As far as is known today, there is no method to oneto-one replicate the formation of this disease in rabbits. Early findings of ANFH can be established in rabbits effectively and reliably with low complication rate with surgical hip dislocation, peripheral cauterization of femoral neck and single dose systemic administration of methylprednisolone. In order to investigate the treatment of late-stage complications of ANFH, autoregenerative processes in animals need to be delayed.

\section{Ethics}

Ethics Committee Approval: The study was carried out following the approval of the Institutional Animal Experiments Ethics Committee of Modena and Reggio Emilia University (2012/07/16-57).

Peer-review: Externally peer reviewed.

Financial Disclosure: This study was carried out with the supports of the European Commission (FP7/2007-2013) REBORNE Project (grant no. 241879); H2020 Programme Orthounion Project (grant no. 733278) and Regions ReggioEmilia Romagna: Programma di Ricerca Regione-Universita 2010-2012-Strategic Program "Regenerative Medicine of Cartilage and Bone" (grant no. PRUa1RI-2012-007).

\section{References}

1. Mont MA, Hungerford DS. Non-traumatic avascular necrosis of the femoral head. J Bone Joint Surg Am 1995;77:459-74.

2. Hwang Y, Park J, Choi SH, Kim G. Traumatic and non-traumatic osteonecrosis in the femoral head of a rabbit model. Lab Animal Res 2011;27:127-31.

3. Wen Q, Ma L, Chen YP, Yang L, Luo W, Wang XN. A rabbit model of hormone-induced early avascular necrosis of the femoral head. Biomed Environ Sci 2008;21:398-408

4. Frost HM. In vivo osteocyte death. J Bone Joint Surg Am 1960;42A:138-43.

5. Phemister DB. The classic: repair of bone in the presence of aseptic necrosis resulting from fractures, transplantations, and vascular obstruction. Clin Orthop Relat Res 2008;466:1021-33.

6. Kawai K, Tamaki A, Hirohata K. Steroid-induced accumulation of lipid in the osteocytes of the rabbit femoral head. A histochemical and electron microscopic study. J Bone Joint Surg Am 1985;67:75563.

7. Motomura G, Yamamoto T, Irisa T, Miyanishi K, Nishida K, Iwamoto Y. Dose effects of corticosteroids on the development of osteonecrosis in rabbits. J Rheumatol 2008;35:2395-99.

8. Yamamoto T, Irisa T, Sugioka Y, Sueishi K. Effects of pulse methylprednisolone on bone and marrow tissues: corticosteroidinduced osteonecrosis in rabbits. Arthritis Rheum 1997;40:2055-64. 
9. Manggold J, Sergi C, Becker K, Lukoschek M, Simank HG. A new animal model of femoral head necrosis induced by intraosseous injection of ethanol. Lab Anim 2002;36:173-80.

10. Qin L, Zhang G, Sheng H, Yeung KW, Yeung HY, Chan CW, Cheung WH, Griffith J, Chiu KH, Leung KS. Multiple bioimaging modalities in evaluation of an experimental osteonecrosis induced by a combination of lipopolysaccharide and methylprednisolone. Bone 2006;39:863-71.

11. Li Y, Han R, Geng C, Wang Y, Wei L. A new osteonecrosis animal model of the femoral head induced by microwave heating and repaired with tissue engineered bone. Int Orthop 2009;33:573-80.
12. Miyanishi K, Yamamoto T, Irisa T, Motomura G, Jingushi S, Sueishi $\mathrm{K}$, Iwamoto Y. Effects of different corticosteroids on the development of osteonecrosis in rabbits. Rheumatology (Oxford) 2005;44:332-6.

13. Wang GJ, Sweet DE, Reger SI, Thompson RC. Fat-cell changes as a mechanism of avascular necrosis of the femoral head in cortisonetreated rabbits. J Bone Joint Surg Am 1977;59:729-35.

14. Zhang-hua L, Wen L, Xi-long C, You-hao C, Tian-shu L, Ming L, Yi Y. Effects of Cbfa1 on osteoanagenesis during avascular necrosis of femoral head. Sci Res Essays 2010;5:2721-2730

15. Song Hj. Peripheral blood Stem cell transplantation for ischemic femoral head necrosis. Transplant Proc 2010;42:1862-1864 